\title{
The Energy Mix Dilemma and Environmental Sustainability: Interaction among Greenhouse Gas Emissions, Nuclear Energy, Urban Agglomeration, and Economic Growth
}

\author{
Abdul Rehman ${ }^{1, *}$,, Hengyun Ma ${ }^{1}\left(\mathbb{D}\right.$, Magdalena Radulescu ${ }^{2,3, *}$, Crenguta Ileana Sinisi ${ }^{4}(\mathbb{D}$, \\ Loredana Maria Paunescu ${ }^{5}$, MD Shabbir Alam ${ }^{6}$ and Rafael Alvarado ${ }^{7}$ \\ 1 College of Economics and Management, Henan Agricultural University, Zhengzhou 450002, China; \\ h.y.ma@163.com \\ 2 Department of Finance, Accounting and Economics, University of Pitesti, 110040 Pitesti, Romania \\ 3 Institute for Doctoral and Post-Doctoral Studies, University "Lucian Blaga" Sibiu, Bd. Victoriei, No. 10, \\ 550024 Sibiu, Romania \\ 4 Department of Management and Business Administration, University of Pitesti, 110040 Pitești, Romania; \\ crengutaileana77@gmail.com \\ 5 Department of Cybernetics, University Gas \& Petroleum, Ploiesti, Bd. Bucuresti, No. 39, \\ 100680 Ploiesti, Romania; loredana.paunescu@yahoo.com \\ 6 Department of Economics \& Finance, College of Business Administration, University of Bahrain, \\ Zallaq P.O. Box 32038, Bahrain; shabbir.alam28@gmail.com \\ 7 Esai Business School, Universidad Espiritu Santo, Samborondon 091650, Ecuador; jose.r.alvarado@unl.edu.ec \\ * Correspondence: abdrehman@henau.edu.cn (A.R.); magdalena.radulescu@upit.ro (M.R.)
}

updates

Citation: Rehman, A.; Ma, H.; Radulescu, M.; Sinisi, C.I.; Paunescu, L.M.; Alam, M.S.; Alvarado, R. The Energy Mix Dilemma and Environmental Sustainability: Interaction among Greenhouse Gas Emissions, Nuclear Energy, Urban Agglomeration, and Economic Growth. Energies 2021, 14, 7703. https://doi.org/10.3390/en14227703

Academic Editor: Nuno Carlos Leitão

Received: 8 October 2021

Accepted: 15 November 2021

Published: 17 November 2021

Publisher's Note: MDPI stays neutral with regard to jurisdictional claims in published maps and institutional affiliations.

Copyright: (c) 2021 by the authors. Licensee MDPI, Basel, Switzerland. This article is an open access article distributed under the terms and conditions of the Creative Commons Attribution (CC BY) license (https:/ / creativecommons.org/licenses/by/ $4.0 /)$.
Abstract: In this paper we examined the interaction between greenhouse gas emissions, nuclear energy, coal energy, urban agglomeration, and economic growth in Pakistan by utilizing time series data during 1972-2019. The stationarity of the variables was tested through unit root tests, while the ARDL (autoregressive distributed lag) method with long and short-run estimations was applied to reveal the linkages between variables. A unidirectional association between all variables was revealed by performing a Granger causality test under the vector error correction model (VECM) that was extracted during the short-run estimate. Furthermore, the stepwise least squares technique was also utilized to check the robustness of the variables. The findings of long-run estimations showed that GHG emissions, coal energy, and urban agglomeration have an adversative association with economic growth in Pakistan, while nuclear energy showed a dynamic association with the economic growth. The outcomes of short-run estimations also show that nuclear energy has a constructive association with economic growth, while the remaining variables exposed an adversative linkage to economic growth in Pakistan. Similarly, the Granger causality test under the vector error correction model (VECM) outcomes exposes that all variables have unidirectional association. Furthermore, the outcomes of the stepwise least squares technique reveals that GHG emissions and coal energy have an adverse association with economic growth, and variables nuclear energy and urban agglomeration have a productive linkage to the economic growth in Pakistan. GHG emissions are no doubt an emerging issue globally; therefore, conservative policies and financial support are needed to tackle this issue. Despite the fact that Pakistan contributes less to greenhouse gas emissions than industrialized countries, the government must implement new policies to address this problem in order to contribute to environmental sustainability while also enhancing economic development.

Keywords: GHG emissions; energy consumption; nuclear energy; economic growth; carbon emission; environment

\section{Introduction}

The consumption of energy has risen dramatically during the past century as a result of many breakthroughs and everyday improvements. As a result, almost every aspect 
of human life is becoming increasingly reliant on energy. Unquestionably, cheap and dependable energy is essential for all nations, but this is especially true for the developing countries. Demand for energy has risen in many nations as a result of increasing industrialization, agricultural modernization, globalization, and better transportation. In the absence of investment in domestic resources such as water power, natural gas, and lignite, Pakistan remains reliant on energy imports. The biggest source of energy is biomass. The government has decided to halt the construction of new coal-fired power plants due to environmental concerns. Public oil and gas companies are considering privatization for a number of reasons [1]. Pakistan is $43.5 \%$ reliant on imported oil for its entire energy mix. The reliance on oil has decreased from 32\% in 2017 to $31.2 \%$ in 2018. Hydropower had a $13.1 \%$ market share in 2018-2019, up from a 7.7\% share compared to the previous year. This decrease in oil's share is good news, but the fall in hydropower's share indicates that the policy is short-sighted and that successive administrations are unable to carry out such capital-intensive projects in a timely way. Pakistan's energy system is 50.4 percent reliant on natural gas, the highest level ever. The country's reliance on natural gas had dwindled to $34.6 \%$ in 2018. The decrease in natural gas reserves and limitations on transportation sector natural gas use, as well as the introduction of LNG (liquefied natural gas) since 2015, all contributed to the fall in the contribution of natural gas to the energy structure. From 2015 to 2018 , the percentage of LNG imports increased from $0.7 \%$ to $8.7 \%$. The position of coal in the energy mix has been static for the last two decades, at about $10 \%$, but, on the other hand, its share in the energy mix, grew to $12.7 \%$ in 2018 [2-4].

The country's energy mix shows a reduction in Pakistan's reliance on thermal energy, such as local and imported coal, RLNG (re-gasified liquefied natural gas), and natural gas. Due to decreasing natural gas reserves and the introduction of liquefied natural gas (LNG), Pakistan's dependence on natural gas is waning throughout its whole energy structure. The availability of renewable energy has risen steadily over time. The administration has also taken efforts to increase the country's usage of hydro and nuclear energy. The energy systems of the globe are experiencing a fast transition, resulting in significant shifts in how we fuel vehicles, heat homes, and generate electricity. Over the next several decades, companies, governments, and people will be impacted by these developments [1]. Countries all around the globe have been working hard over the last two decades to decrease global warming and prevent the harmful effects of global warming. $\mathrm{CO}_{2}$ emissions from fossil fuel combustion has received a large amount of attention, since they are the primary cause of climate change. As a result, the goal is to enhance the energy supply sector while decreasing greenhouse gas emissions, in order to provide safer and cheaper energy. Any effort must include the investigation of fossil fuel substitutes. Nuclear energy, as well as renewable energy sources such as solar, hydropower, biomass, wind, and geothermal power, may provide solutions for energy security and climate change [5-7]. However, the link between greenhouse gas emissions and the utilization of renewable and nuclear energy may not be as simple as it seems. Furthermore, even if the construction of new nuclear or renewable energy facilities leads to the closure of coal-fired power plants, the price of coal may fall, encouraging other energy consumers to use coal instead of clean energy, thus increasing overall $\mathrm{CO}_{2}$ emissions [8].

Excessive use of fossil fuels, which results in greenhouse gases emissions, has recently risen to the top of the environmental priority list, particularly in developing economies. As a consequence of their fast economic development and huge populations, the energy consumption and production patterns of these nations may have an impact on global issues such as global warming. As previously said, energy is critical to economic progress, but it is vital to address the environmental consequences of rising energy use, particularly in the early phases, if sustainable development objectives are to be achieved [9-11]. In the circular economy, production and consumption are intertwined in an effort to reduce pollution. Since its conception, this paradigm has been developed and affected by many areas of evidence, allowing it to be systematized and somewhat re-adapted to meet today's concerns [12]. To combat environmental problems, the circular economy is becoming more 
prominent. Economic, environmental, and social advantages all come together in a circular economy. Nevertheless, the global economy has a relatively low degree of circularity, and opponents point out that existing theories have not delivered the promised effects on a societal level that is sustainable. Resource reserves and energy flow are largely dependent on human progress and development as important system components. Human activities must be coordinated with the earth's biosphere in order to alleviate pressure from the technological circle, which we have provided a conceptual framework to achieve [13,14].

In the circular economy, resources are better used, natural systems are rejuvenated, and waste is reduced while goods and materials are maintained in use. However, the circular economy's social implications are non-existent. Furthermore, there is no comprehensive framework for choosing social indicators to assess whether circular economy methods have a beneficial or negative effect [15]. Furthermore, environmental awareness and sustainable development are inseparable from the contemporary supply chain's image. The quest for sustainable supply chain management may be attributed to the contemporary world's demands. Improving a company's image while simultaneously reducing waste, innovating, creating revenues, and gaining a competitive edge are all possible with efficient use and proper management of natural resources. The high intensity of the circular economy is linked to accreditation of environmental management systems and strategic decisions for environmental performance improvement and sustainable business models. However, managing distributed energy has enhanced the generation and delivery of more scattered energy [16-18]. Issues in energy policy, high power generating prices, old infrastructure, and inadequate power transmission have all contributed to the severe energy crisis. In addition to transmission loss and distribution theft, Pakistan's power corporations have a bureaucratic culture of inadequate management and planning. The notion of energy efficiency is still underappreciated, in part because many feel that energy efficiency is a tool to decrease consumption and output rather than increase it. Due to the country's perception that economic progress is essential to its future, energy efficiency has been seen as a euphemism for slowing growth. The current study makes a unique contribution to the existing literature and supports Pakistan's future development plans by identifying long-term connections between energy production, activities, fuel use, and technical advancements. The findings of this research are relevant to the growing demand of energy, including coal and nuclear energy, in Pakistan in order to foster economic growth. With this motive, the current study's major aim was to examine the interaction between greenhouse gas emissions, nuclear energy, coal energy, urban agglomeration, and economic growth in Pakistan by utilizing time series data during 1972-2019. Threeunit root tests were utilized to rectify the stationarity of the variables, while the ARDL (autoregressive distributed lag) method with long and short-run estimations was employed to reveal the linkages between variables. The Granger causality test under the vector error correction model was also employed to show a unidirectional relationship among all variables. Furthermore, the stepwise least square technique was also utilized to check the robustness of the variables.

\section{Literature Review}

The increasing usage of polluting energy sources has contributed to climate change, which is a consequence of fossil fuels. This shift has had an effect on both people and the environment. If greenhouse gas (GHG) emissions continue to rise, the climate system as a whole will warm up and undergo long-term alterations. In terms of population health and environmental quality, $\mathrm{CO}_{2}$ emissions are increasing at an alarming pace $[19,20]$. Governments, international organizations, and other parties are increasingly concerned with sustainable development as a means of achieving both stable economic growth and long-term environmental quality. This is due to theses groups realizing the connection between growing carbon emissions and the damage to environmental and human health caused by the increased usage of energy in economic development, particularly energy derived from carbon-related sources. As a consequence, developing countries believe that 
boosting funding for global warming efforts, which are mostly led by industrial economies, is critical if their economies are to continue growing while using less carbon-intensive energy [21-23].

The challenge of balancing economic growth with environmental preservation is now being widely debated across the world. Because of the global economy's rapid expansion, climate change has placed the lives of humans and other species in jeopardy [24]. This requires improving energy efficiency, which should result in lower energy demand per unit of GDP in the economy as well as lower greenhouse gas emissions, while also identifying long-term sustainable alternatives to fossil fuels. The growing cost of energy, as well as global strategic goals for reducing air pollution, need a deeper investigation into the link between renewable energy consumption and economic development $[25,26]$. Individuals, corporations, and governments have all shown interest in tackling these environmental challenges as they become more aware of the environmental impact of carbon emissions and global warming. Carbon emissions are calculated using numerous parameters, the most significant of which is the total amount of greenhouse gases released. Today's world recognizes the importance of these emissions in terms of economy, society, and politics, as well as the necessity of reducing them in order to combat climate change. People also assume that environmental changes are caused by economic growth, rather than the other way around. However, the direction and type of causality may differ among countries [27-29].

The fast rise in energy use has resulted in serious environmental problems, such as huge emissions of greenhouse gases such as carbon dioxide, which is the primary driver of global warming. Clean energy, such as renewable energy, has replaced conventional fossil fuels as a result of growing environmental and public health concerns over carbon dioxide emissions. Reducing carbon dioxide emissions and combating climate change may be achieved by using renewable energy sources. Energy policy across the world has shifted to emphasize using more renewable energy sources [30,31]. In developed nations, environmental deterioration is the most difficult issue to solve. Stopping the degradation of the environment is futile in a particular economy. High levels of greenhouse gas emissions are having an impact on industrialization throughout the world, especially in economies that are not held accountable. Increased greenhouse gas emissions result from countries use of energy and other natural resources to maximize economic development. Carbon dioxide emissions are a significant contributor to the deterioration of the environment caused by greenhouse gases [32-34].

Increased worldwide temperatures, unpredictability in weather patterns, and air pollution have all been linked to environmental pollution. Other threats to human health and well-being have come as a result of these and other negative environmental consequences. The use of fossil fuels is mostly responsible for global warming. Carbon dioxide $\left(\mathrm{CO}_{2}\right)$ emissions are the primary source of greenhouse gas pollution. As carbon dioxide emissions grow in intensity and complexity, it is more critical than ever to pay attention to alternative energy production alternatives. Furthermore, the general public and policymakers are becoming increasingly concerned about fossil fuel use and energy security problems, as well as greenhouse gas emissions. Nuclear and renewable sources of energy have appeared as viable alternatives to cope with climate change's threats, particularly sea level rise [35-38]. Energy, which is a key component in manufacturing, drives economic development and advancement. A better quality of life is prevalent in countries with greater energy usage. The consumption of energy also leads to the production of different greenhouse gases, such as carbon dioxide, which degrade the environment. This means that even after 30 years, energy consumption and its role in carbon dioxide emissions remains the most contentious and divisive topic among environmental economists and policymakers [39-41].

Non-renewable energy dependence has raised significant concerns and difficulties across the globe. These include concerns about non-renewable energy depletion, as well as concerns about energy security and environmental issues in general. Since these significant problems and concerns have emerged in the last several decades, governments across the 
world have focused on renewable energy and investments related to renewable energy technology. The management and planning of energy resources is increasingly intimately linked to sustainable development and is an essential component of economic progress. There is a huge demand-supply discrepancy, fossil fuel import costs are increasing, and air pollution is worsening. The search for affordable, efficient, and environmentally friendly energy sources is essential right now. It is little wonder that renewable energy has lately garnered a lot of attention. Renewable energy is essential to combating global warming, since energy is regarded as the cornerstone of economic prosperity and social well-being. There is always a conventional output factor for energy status. As a result of the reliance on oil for development, there is also a pressing need for continuous and abundant economic expansion [42-46]. Economic development and growth are inextricably tied to the health of a country's energy sector. Pakistan has faced serious issues in recent decades as a result of the country's continuous energy shortage. Because of the rapid increase in demand, the electricity sector has received a lot of attention recently. Similar to this, the nation has additional problems such as inadequate availability of water, pollution in the water and air, and deterioration of pasturelands. Electricity, as a source of energy, is critical for a country's overall economic development, not only for the manufacturing sector. The generation of sustainable energy may enhance quality of life and societal well-being [47,48].

$\mathrm{CO}_{2}$ emissions from urban and industrial fossil fuel usage are becoming increasingly recognized as an unknown contribution to global warming, especially in the industrialized economies, which are among the world's largest energy consumers. As a consequence, sustainable development strategies are increasingly focused on energy-saving and lowcarbon economic growth. The impact of nuclear energy consumption on economic growth is scarcely analyzed in the literature and the results are very mixed. Magazzino et al. [49] found an adverse effect of nuclear energy use on economic growth in Switzerland using an AI and machine learning approach during 1970-2018. Saidi and Mbarek [50] investigated a panel of developed countries during 1990-2013 using a dynamic panel regression and found no causality between nuclear energy and economic growth [50]. Christoforidis et al. [51] found a positive impact of nuclear energy consumption on economic growth in 18 top nuclear-energy consuming countries during 1995-2017 using PM and PMG estimators. Mbarek et al. [52] investigated the dynamic link between economic growth and nuclear energy production in France based on a VECM model during 1990-2011 and found bi-directional causality and a positive effect of nuclear energy production on economic growth.

Urban agglomerations have also emerged as the most active and promising regional entities, in charge of guiding both the modernization of the industrial structure and the future expansion of the regional economy. Due to their large energy use, the resulting urban agglomerations will face significant pressure to reduce emissions [53,54]. Because of the global population increase, particularly in emerging countries, governments and policymakers in various nations face a variety of problems. Most of the population is supplied with new facilities every year, increasing the overall population and putting further strain on limited natural resources. Khan and Awan [55] proved in their study for Pakistan that the urban agglomeration positively and significantly impacted economic growth, especially in the urban area. Ahrend et al. [56] also proved a positive relationship between urban agglomeration and economic growth for OECD regions. Asowga et al. [57] found a positive association between urban agglomeration and economic growth for a panel of sub-Saharan African countries during 1970-2019. Jayasooriya [58] also demonstrated a positive association between urban agglomeration and economic growth for regions in China using a GMM method during 2004-2015. The same results were achieved by Liu and Du [59] for China.

Today's fundamental demand fulfillment depends on the energy sector's contribution both directly and indirectly. Proper use and management of the energy sector may thus be a solution for feeding and protecting the people of the globe [60,61]. A low-carbon energy transition helps mitigate climate change, reduce air pollution, and slow the depletion of 
fossil fuels. Uncontrolled economic expansion threatens global ecology due to the limited structure of natural resources. No economic activity may take place unless energy is provided as an input $[62,63]$.

\section{Methods and Study Data}

The major aim of the current study was to determine the interaction between GHG emissions, nuclear energy, coal energy, and urban agglomeration to economic progress in Pakistan by using annual data which is taken from the two key sources: the Economic Survey of Pakistan (https: / / www.finance.gov.pk/, accessed on 14 September 2021) and the World Development Indicators (https: / / data.worldbank.org/country/pakistan, accessed on 14 September 2021). The explanation of all variables utilized in this study is illustrated in Figure 1, which reveals the upward and downward tendencies from 1972-2019. Furthermore, Figure 2 shows the methodological approach of this study. First, we checked the variables' summary analysis and correlation, then their stationarity through the unit root tests (DF-GLS, P-P, KPSS). After, the bounds were tested for the confirmation of cointegration with the Johansen cointegration test, and short and long-run estimations using ARDL technique including stability and diagnostic tests were used. A unidirectional association between all variables was revealed by performing a Granger causality test under the vector error correction model (VECM). Finally, we employed the stepwise least squares technique to enhance the robustness of the findings.

\subsection{Econometric Model Demonstration}

For demonstrating the interaction among GHG emissions, nuclear energy, coal energy, urban agglomeration, and economic growth in Pakistan, we have utilized the following model, which can be stated as:

$$
E C G_{t}=f\left(G H G e_{t}, N U E N_{t}, C O E N_{t}, U R A G_{t}\right)
$$

For further explanation of variables, we can expand Equation (1) further as:

$$
\operatorname{LnECG}_{t}=\pi_{0}+\pi_{1} \operatorname{LnGHGe}_{t}+\pi_{2} \operatorname{LnNUEN}_{t}+\pi_{3} \operatorname{LnCOEN}_{t}+\pi_{4} \operatorname{LnURAG}_{t}+\varepsilon_{t}
$$

where in Equation (2), $E C G_{t}$ signifies economic growth, $G H G e_{t}$ reflects greenhouse gas emissions, NUEN $N_{t}$ displays nuclear energy, COEN $N_{t}$ indicates coal energy, and $U R A G_{t}$ presents urban agglomeration. The coefficients from $\pi_{1}$ to $\pi_{4}$ show the model dynamics. 


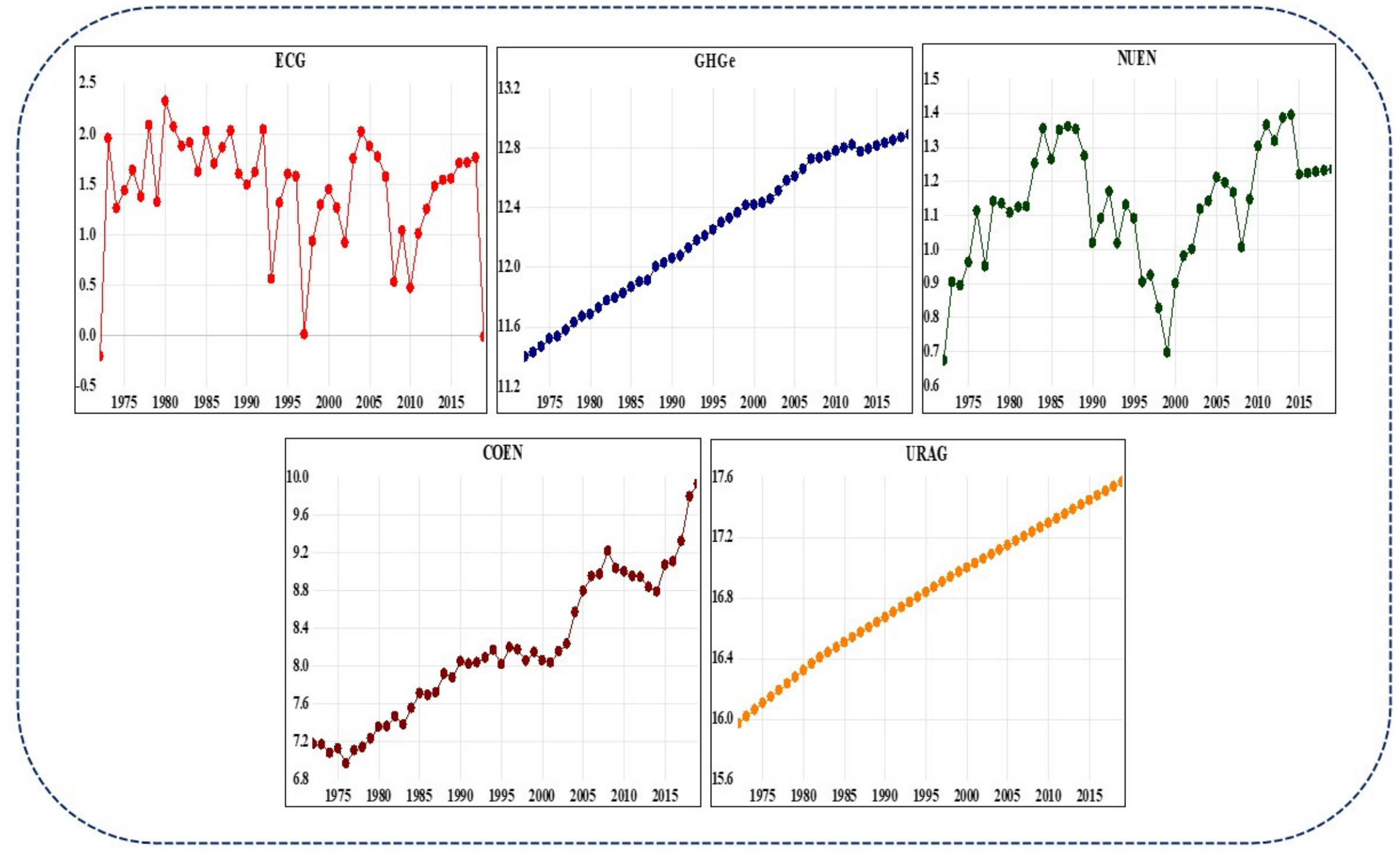

Figure 1. Trends of the variables used in the study. 


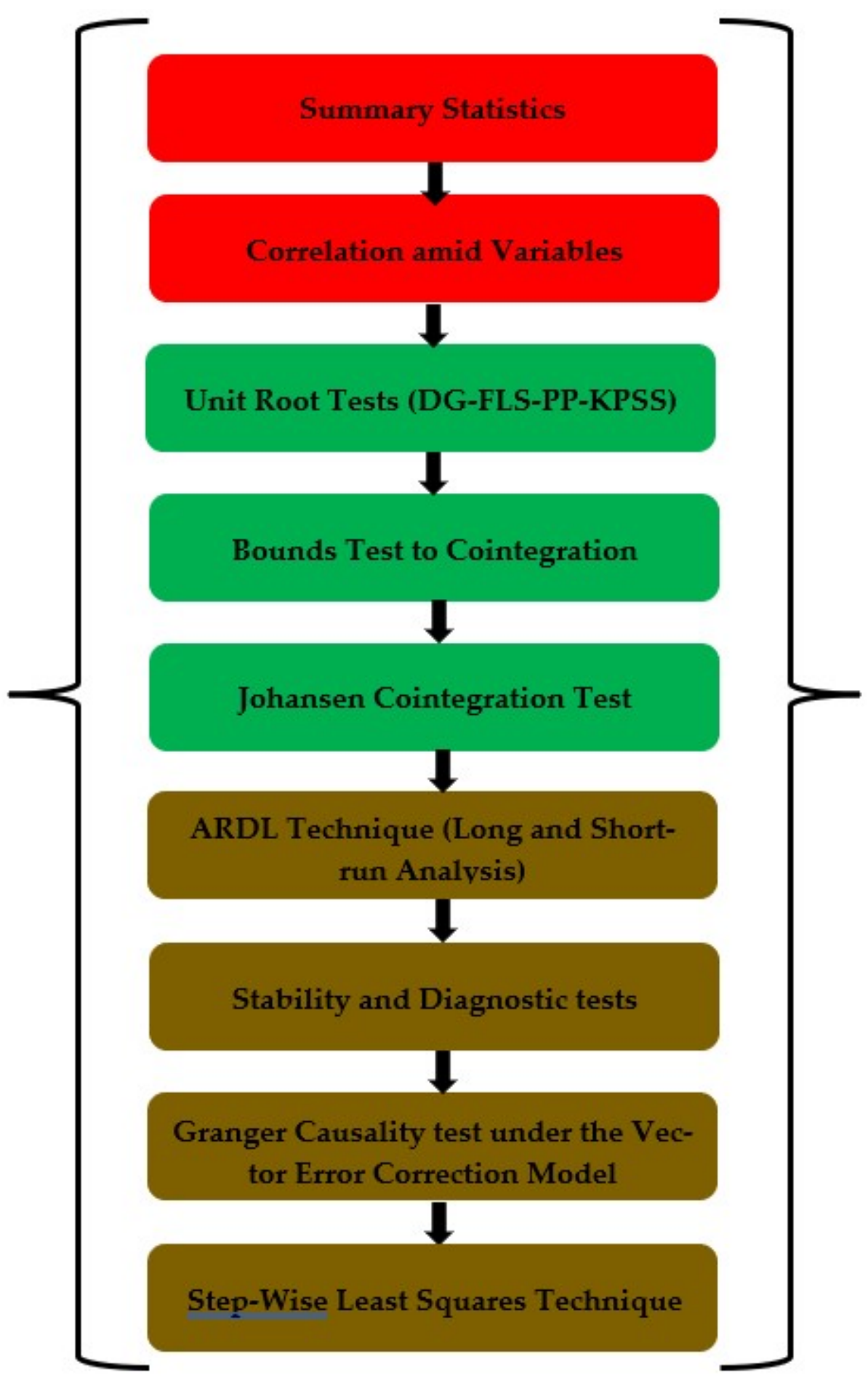

Figure 2. The methodological framework of the study.

\subsection{Specification of ARDL Technique}

This study has followed the technique of ARDL bounds testing, which was presented by Pesaran and Shin [64] and Pesaran et al. [65]. Long-term and short-term connections between variables like economic growth and all others are shown by the integrated order $\mathrm{I}(0)$ and I(1), but not at I(2). The variables' interaction with the unrestricted error correction model (UECM) may be summarized as follows: 


$$
\begin{aligned}
& \Delta L n E C G_{t}=\tau_{0}+\sum_{b=1}^{b} \tau_{1 b} \Delta L n E C G_{t-r}+\sum_{b=1}^{b} \tau_{2 b} \Delta L n G H G e_{t-r} \\
& +\sum_{b=1}^{b} \tau_{3 b} \Delta \operatorname{LnNUEN} N_{t-r}+\sum_{b=1}^{b} \tau_{4 b} \Delta \operatorname{LnCOEN} N_{t-r} \\
& +\sum_{b=1}^{b} \tau_{5 b} \Delta \operatorname{LnURAG_{t-r}}+\tau_{6} \operatorname{LnECG_{t-1}}+\tau_{7} \operatorname{LnGHGe_{t-1}} \\
& +\tau_{8} \operatorname{LnNUEN}_{t-1}+\tau_{9} \operatorname{LnCOEN_{t-1}}+\tau_{10} \operatorname{LnURAG_{t-1}}+\varepsilon_{1 t} \\
& \Delta L n G H G e_{t}=\theta_{0}+\sum_{g=1}^{g} \theta_{1 g} \Delta L n G H G e_{t-l}+\sum_{g=1}^{g} \theta_{2 g} \Delta L n E C G_{t-l} \\
& +\sum_{g=1}^{g} \theta_{3 g} \Delta L n N U E N_{t-l}+\sum_{g=1}^{g} \theta_{4 g} \Delta \operatorname{LnCOEN}_{t-l}
\end{aligned}
$$

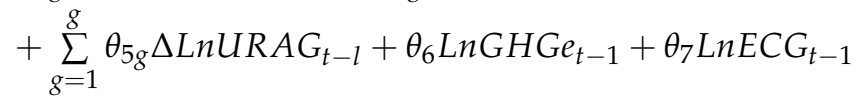

$$
\begin{aligned}
& +\theta_{8} \operatorname{LnNUEN}_{t-1}+\theta_{9} \operatorname{LnCOEN}_{t-1}+\theta_{10} \operatorname{LnURAG}_{t-1}+\varepsilon_{2 t} \\
& \Delta \operatorname{LnNUEN}_{t}=\alpha_{0}+\sum_{u=1}^{u} \alpha_{1 u} \Delta \operatorname{LnNUEN_{t-m}}+\sum_{u=1}^{u} \alpha_{2 u} \Delta L n G H G e_{t-m} \\
& +\sum_{u=1}^{u} \alpha_{3 u} \Delta \operatorname{LnECG} G_{t-m}+\sum_{u=1}^{u} \alpha_{4 u} \Delta \operatorname{LnCOEN}_{t-m} \\
& +\sum_{u=1}^{u=1} \alpha_{5 u} \Delta \operatorname{LnURAG_{t-l}}+\alpha_{6} \operatorname{LnNUEN}_{t-1}+\alpha_{7} \operatorname{LnGHG}_{t-1} \\
& +\alpha_{8} \operatorname{LnECG_{t-1}}+\alpha_{9} \operatorname{LnCOEN}_{t-1}+\alpha_{10} \operatorname{Ln} U R A G_{t-1}+\varepsilon_{3 t} \\
& \Delta \operatorname{LnCOEN} N_{t}=\eta_{0}+\sum_{w=1}^{w} \eta_{1 w} \Delta L n C O E N_{t-j}+\sum_{w=1}^{w} \eta_{2 w} \Delta L n N U E N_{t-j} \\
& +\sum_{w=1}^{w} \eta_{3 w} \Delta L n G H G e_{t-j}+\sum_{w=1}^{w} \eta_{4 w} \Delta L n E C G_{t-j} \\
& +\sum_{w=1}^{w=} \eta_{5 w} \Delta \operatorname{LnURAG_{t-l}}+\eta_{6} \operatorname{LnCOEN}_{t-1}+\eta_{7} \operatorname{LnNUEN}_{t-1} \\
& +\eta_{8} \operatorname{LnGHGe}_{t-1}+\eta_{9} \mathrm{LnECG}_{t-1}+\eta_{10} \operatorname{LnURAG}_{t-1}+\varepsilon_{4 t} \\
& \Delta \operatorname{LnURAG_{t}}=\omega_{0}+\sum_{p=1}^{p} \omega_{1 p} \Delta \operatorname{LnURAG_{t-f}}+\sum_{p=1}^{p} \omega_{2 p} \Delta \operatorname{LnCOEN} N_{t-f} \\
& +\sum_{p=1}^{p} \omega_{3 p} \Delta L n N U E N_{t-f}+\sum_{p=1}^{p} \omega_{4 p} \Delta L n G H G e_{t-f} \\
& +\sum_{p=1}^{p} \omega_{5 p} \Delta \operatorname{LnECG_{t-f}}+\omega_{6} \operatorname{LnURAG_{t-1}}+\omega_{7} \operatorname{LnCOEN}_{t-1} \\
& +\omega_{8} \operatorname{LnNUEN}_{t-1}+\omega_{9} \operatorname{LnGHGe_{t-1}}+\omega_{10} \operatorname{LnECG}_{t-1}+\varepsilon_{6 t}
\end{aligned}
$$

The difference from Equations (3)-(7) is explored via $\Delta$, and error terms are illustrating via $\varepsilon_{1 t}-\varepsilon_{6 t}$. Similarly, the parameters used in these equations are: $\tau_{1}-\tau_{5}, \theta_{1}-\theta_{5}, \alpha_{1}-\alpha_{5}, \eta_{1}-\eta_{5}$, $\beta_{1}-\beta_{5}$, and $\omega_{1}-\omega_{5}$, showing the short-run coefficients, while $\tau_{6}-\tau_{10}, \theta_{6}-\theta_{10}, \alpha_{6}-\alpha_{10}, \eta_{6}-\eta_{10}, \beta_{6^{-}}$ $\beta_{10}$, and $\omega_{6}-\omega_{10}$ uncover the long-run coefficients in the model. With the ARDL technique, it is possible to confirm the dynamic linkage between the analyzed variables. The null hypothesis has been rejected, which implies there are linkages and interactions between invaders, and reliance on the interlopers' ingenuity.

\subsection{Causality Association among Variables via VECM (Vector Error Correction Model)}

The cointegration consistency of the model has been evaluated by long- and short-run successes among specified variables under the ARDL model. The results demonstrate a pattern of correlation between variables that cannot be defined. The vector error correction model's causal check additionally tracks variable sources by proving their importance across current values. Engle and Granger (1987) [66] established the VECM model for 
categorizing and determining the direction of causal link. A short-run test with an error correction term (ECT) in the provided model is performed in the long-run analysis if the variables are merged using the autoregressive distributed lag (ARDL) technique or the vector error correction model (VECM). If the variables being studied are not cointegrated, the short-term investigation focuses on a typical vector-autoregressive (VAR) model. The vector error correction model is interpreted as follows in Equation (8):

$$
\begin{aligned}
& {\left[\begin{array}{c}
\Delta \text { LnECG }_{t} \\
\Delta \text { LnGHGe }_{t} \\
\Delta \text { LnNUEN }_{t} \\
\Delta \text { LnCOEN } \\
\Delta \text { LnURAG }
\end{array}\right]=\left[\begin{array}{c}
\tau_{1} \\
\tau_{2} \\
\tau_{3} \\
\tau_{4} \\
\tau_{5}
\end{array}\right]+\left[\begin{array}{c}
\tau_{11,1} \tau_{12,1} \tau_{13,1} \tau_{14,1} \tau_{15,1} \\
\tau_{21,1} \tau_{22,1} \tau_{23,1} \tau_{24,1} \tau_{25,1} \\
\tau_{31,1} \tau_{32,1} \tau_{33,1} \tau_{34,1} \tau_{35,1} \\
\tau_{41,1} \tau_{42,1} \tau_{43,1} \tau_{44,1} \tau_{45,1} \\
\tau_{51,1} \tau_{52,1} \tau_{53,1} \tau_{54,1} \tau_{55,1}
\end{array}\right]} \\
& {\left[\begin{array}{c}
\Delta \text { LnECG }_{t-1} \\
\Delta \text { LnGHGe }_{t-1} \\
\Delta \text { LnNUEN } N_{t-1} \\
\Delta \text { LnCOEN } N_{t-1} \\
\Delta \text { LnURAG } G_{t-1}
\end{array}\right]+\ldots+\left[\begin{array}{c}
\tau_{11, k} \tau_{12, k} \tau_{13, k} \tau_{14, k} \tau_{15, k} \\
\tau_{21, k} \tau_{22, k} \tau_{23, k} \tau_{24, k} \tau_{25, k} \\
\tau_{31, k} \tau_{32, k} \tau_{33, k} \tau_{34, k} \tau_{35, k} \\
\tau_{41, k} \tau_{42, k} \tau_{43, k} \tau_{44, k} \tau_{45, k} \\
\tau_{51, k} \tau_{52, k} \tau_{53, k} \tau_{54, k} \tau_{55, k}
\end{array}\right]} \\
& {\left[\begin{array}{c}
\Delta \text { LnECG }_{t-k} \\
\Delta \text { LnGHGe }_{t-k} \\
\Delta \text { LnNUEN }_{t-k} \\
\Delta \text { LnCOEN } \\
\Delta L n U R A G_{t-k}
\end{array}\right]+\left[\begin{array}{c}
\phi_{1} \\
\phi_{2} \\
\phi_{3} \\
\phi_{4} \\
\phi_{5}
\end{array}\right] E C T_{t-1}+\left[\begin{array}{c}
\vartheta_{1} \\
\vartheta_{2} \\
\vartheta_{3} \\
\vartheta_{4} \\
\vartheta_{5}
\end{array}\right]}
\end{aligned}
$$

where $\Delta$ indicates the operator which exposes the difference in Equation (8), $\vartheta$ demonstrates the classification of error term, and " $\phi$ " exposes the error term $\left(E C T_{t-1}\right)$ coefficient.

\section{Outcomes and Discussion}

\subsection{Summary Analysis}

Table 1 shows the results of the summary statistics with probability values of the variables economic growth, greenhouse gas emissions, nuclear energy, coal energy, and urban agglomeration.

Table 1. Summary statistics results.

\begin{tabular}{cccccc}
\hline & LnECG & LnGHGe & LnNUEN & LnCOEN & LnURAG \\
\hline Mean & 1.439 & 12.232 & 1.124 & 8.163 & 16.828 \\
Median & 1.576 & 12.276 & 1.138 & 8.059 & 16.855 \\
Maximum & 2.323 & 12.888 & 1.394 & 9.931 & 17.567 \\
Minimum & -0.206 & 11.400 & 0.674 & 6.970 & 15.971 \\
Std. Dev. & 0.568 & 0.475 & 0.175 & 0.766 & 0.463 \\
Skewness & -1.220 & -0.184 & -0.550 & 0.328 & -0.163 \\
Kurtosis & 4.147 & 1.689 & 2.841 & 2.255 & 1.887 \\
Jarque-Bera & 14.543 & 3.705 & 2.476 & 1.971 & 2.686 \\
Probability & 0.000 & 0.156 & 0.289 & 0.373 & 0.260 \\
\hline
\end{tabular}

\subsection{Correlation among Variables}

The correlations among variables are reported in Table 2 and results show that all variables, including economic growth, greenhouse gas emissions, nuclear energy, coal energy, and urban agglomeration, are correlated. 
Table 2. Results of correlation.

\begin{tabular}{cccccc}
\hline & LnECG & LnGHGe & LnNUEN & LnCOEN & LnURAG \\
\hline LnECG & 1.000 & -0.218 & 0.355 & -0.251 & -0.196 \\
LnGHGe & -0.218 & 1.000 & 0.330 & 0.956 & 0.995 \\
LnNUEN & 0.355 & 0.330 & 1.000 & 0.362 & 0.362 \\
LnCOEN & -0.251 & 0.956 & 0.362 & 1.000 & 0.958 \\
LnURAG & -0.196 & 0.995 & 0.362 & 0.958 & 1.000 \\
\hline
\end{tabular}

\subsection{Unit Root Testing}

We investigated the integration order of each variable such as economic growth, greenhouse gas emissions, nuclear energy, coal energy, and urban agglomeration by using the Dickey Fuller (DF-GLS) [67], Philips-Perron (PP) [68], and KPSS [69] unit root tests. Table 3 shows the findings for local clusters as well. The test statistics and probability values of the variables show whether a series is stationary or not. It turns out that the variables of the model are non-stationary at this level, but they become stationary when the integration order is changed by a single step at I(1).

Table 3. Results of unit root test.

\begin{tabular}{|c|c|c|c|c|c|}
\hline \multicolumn{6}{|c|}{ Dickey-Fuller GLS Tests (At Level) } \\
\hline & LnECG & LnGHGe & LnNUEN & LnCOEN & LnURAG \\
\hline T-S ( $p$-values $\left.{ }^{*}\right)$ & $-2.492 * *(0.016)$ & $-0.266(0.791)$ & $-1.428(0.159)$ & $1.886 *(0.065)$ & $1.603(0.115)$ \\
\hline \multicolumn{6}{|c|}{ At First Difference } \\
\hline T-S ( $p$-values *) & $-0.139 * *(0.016)$ & $-6.125^{* * *}(0.000)$ & $-1.312(0.196)$ & $-3.290^{* * *}(0.002)$ & $-0.473(0.638)$ \\
\hline \multicolumn{6}{|c|}{ P-P Test (At Level) } \\
\hline T-S ( $p$-values $\left.{ }^{*}\right)$ & $-5.881^{* * *}(0.000)$ & $-2.202(0.208)$ & $-3.125 *(0.031)$ & $0.685(0.990)$ & $-5.973^{* * *}(0.000)$ \\
\hline \multicolumn{6}{|c|}{ At First Difference } \\
\hline T-S $\left(p\right.$-values $\left.{ }^{*}\right)$ & $-16.385^{* * *}(0.000)$ & $-6.140^{* * *}(0.000)$ & $-7.862^{* * *}(0.000)$ & $-6.329^{* * *}(0.000)$ & $-2.485(0.125)$ \\
\hline \multicolumn{6}{|c|}{ KPSS Test (At Level) } \\
\hline T-S ( $p$-values $\left.{ }^{*}\right)$ & $0.258^{* * *}(0.000)$ & $0.901(0.000)$ & $0.201^{* * *}(0.000)$ & $0.889^{* * *}(0.000)$ & $0.909^{* * *}(0.000)$ \\
\hline \multicolumn{6}{|c|}{ At First Difference } \\
\hline T-S $(p$-values *) & $0.396(0.966)$ & $0.455^{* * *}(0.000)$ & $0.143(0.454)$ & $0.168^{* * *}(0.005)$ & $0.715^{* * *}(0.000)$ \\
\hline
\end{tabular}

Note: ${ }^{*}{ }^{* *},{ }^{* * *}$ indicate the level of significance at $1 \%, 5 \%$, and $10 \%$.

\subsection{Bounds Testing to Cointegration}

Table 4 displays the results of bounds testing for the validation of cointegration. In this case, the meaning range is $10 \%, 5 \%, 2.5 \%$, and $1.0 \%$, and cointegration determination is achieved at the top and lower limits (F-statistic value: 10.27825). This technique demonstrates the long-term interactions of variables and their connections by utilizing bonds testing to establish integration.

Furthermore, to investigate cointegration in model variables, the Johansen cointegration method [70] was used. Table 5 displays the outcomes of this approach. The frequency of lags is calculated using the Akaike Information Criteria (AIC). The hypothesis of the no cointegration in the model is rejected at a 5\% significance level based on tracing and maximum eigenvalue testing. Cointegration demonstrates a long-term connection between the analyzed variables. As a result, certain variable pairs may be placed together, because the majority of variables suggest that the null hypothesis can be rejected and the variables have a long-term relationship. 
Table 4. Results of bounds testing.

\begin{tabular}{|c|c|c|c|c|}
\hline \multicolumn{2}{|c|}{ F-Bounds Test } & \multicolumn{3}{|c|}{ N-Hypothesis (No Levels Relationship) } \\
\hline T-Statistic & Value & Signif. & $\mathbf{I}(0)$ & I(1) \\
\hline & & & [Asymptotic: $\mathrm{n}=1000]$ & \\
\hline F-Statistic & [10.27825] & {$[10 \%]$} & {$[2.2]$} & [3.09] \\
\hline \multirow[t]{3}{*}{$\mathrm{K}$} & 4 & {$[5 \%]$} & {$[2.56]$} & [3.49] \\
\hline & & {$[2.5 \%]$} & [2.88] & [3.87] \\
\hline & & {$[1 \%]$} & [3.29] & [4.37] \\
\hline \multirow[t]{8}{*}{ Actual Sample Size } & 47 & & [Finite Sample: $\mathrm{n}=50$ ] & \\
\hline & & {$[10 \%]$} & [2.372] & {$[3.32]$} \\
\hline & & {$[5 \%]$} & [2.823] & [3.872] \\
\hline & & {$[1 \%]$} & [3.845] & {$[5.15]$} \\
\hline & & & [Finite Sample: $n=45$ ] & \\
\hline & & {$[10 \%]$} & {$[2.402]$} & [3.345] \\
\hline & & [5\%] & [2.85] & [3.905] \\
\hline & & {$[1 \%]$} & [3.892] & [5.173] \\
\hline
\end{tabular}

Table 5. Results of J-cointegration.

\begin{tabular}{ccccc}
\hline \multicolumn{5}{c}{ Trace Test Statistics } \\
\hline No. of Hypo. CE(s) & E-Value & T-Statistic & C-Value at 5\% & Prob. ${ }^{* *}$ \\
\hline None * & $0.641^{* * *}$ & 87.494 & 69.818 & 0.001 \\
Maximum at ${ }^{*}$ & 0.415 & 40.278 & 47.856 & 0.212 \\
Maximum at 2 & 0.151 & 15.539 & 29.797 & 0.744 \\
Maximum at 3 & 0.139 & 7.970 & 15.494 & 0.468 \\
Maximum at 4 & 0.023 & 1.073 & 3.841 & 0.300 \\
\hline \multicolumn{5}{c}{ Max-Eigenvalue Test Statistics } \\
\hline No. of Hypo. CE(s) & E-Value & T-Statistic & C-Value at 5\% & Prob. ${ }^{* *}$ \\
\hline None * & $0.641 * * *$ & 47.215 & 33.876 & 0.000 \\
Maximum at $1{ }^{*}$ & 0.415 & 24.739 & 27.584 & 0.110 \\
Maximum at 2 & 0.151 & 7.568 & 21.131 & 0.928 \\
Maximum at 3 & 0.139 & 6.897 & 14.264 & 0.501 \\
Maximum at 4 & 0.023 & 1.073 & 3.841 & 0.300
\end{tabular}

Note: ${ }^{*}{ }^{* * *}$ show the denial of the hypothesis at the level of $5 \%$ and $10 \% ;{ }^{* *}$ indicates the probability values of (MacKinnon-Haug-Michelis 1999).

\subsection{Long-Run and Short-Run Dynamics}

The autoregressive distributed lag approach was utilized to investigate the interaction between variables via short and long-run estimates. The results of the short and long-run analysis are shown in Table 6.

The short-run results in Table 6 show that the variable of nuclear energy consumption has a positive coefficient (1.852) with probability value (0.003), which exposes a constructive linkage to economic growth, while the variables greenhouse gas emissions, coal energy usage, and urban agglomeration have an adversative association to economic progress in Pakistan. Moving to the consequences of the long-run estimations, the variable of nuclear energy has a positive coefficient (1.781) with probability value (0.001), which uncovers a constructive association to economic growth. The variables greenhouse gas emissions, coal energy usage, and urban agglomeration show an adverse linkage to economic growth in Pakistan. Oil supplanted coal because it was more efficient. As the world's population grows, cities expand, and new goods are developed, the need for oil rises. Oil is necessary for transportation as well as for the production of electric power. Because of its availability and cheap cost in comparison to other energy sources, oil became the primary option for meeting global energy and economic requirements [71]. Because of expanding problems such as environmental degradation, global warming, and the need for energy fairness, human dignity has grown in relevance. Energy is essential in the production process 
since it acts as both capital and labor. Energy consumption, on the other hand, supports economic growth in many countries, but this consumption also contributes considerably to the rising trend of pollution. As a result, concerns about the environmental consequences of economic expansion are prominent. Measures to encourage energy innovation may help in the attempt to reduce pollution. However, fossil fuels are currently the predominant source of energy for the generation of electricity. Increased nuclear energy output may help to halt global warming. Nuclear energy may be used to create electricity. The most important responsibility is to address environmental concerns. Nuclear energy also supports the achievement and protection of environmental sturdiness through its use. Low-carbon outflows may arise by using nuclear energy, which is a reliable and well-known source of energy [72-75]. It is important to remember that the connection between energy use and economic development includes both consumer problems and environmental considerations as well. Since conventional energy sources such as coal pollute the environment, their usage reflects current local environmental pressure to some extent, to say nothing of global pressure [76,77].

Table 6. Results of short and long-run analysis.

\begin{tabular}{|c|c|c|c|c|}
\hline \multicolumn{5}{|c|}{ Short-Run Results } \\
\hline Variables & Coefficients & S-Error & t-Stat. & Prob. \\
\hline $\mathrm{C}$ & -1.523 & 2.444 & -0.623 & 0.536 \\
\hline LnECG(-1) & $-1.039 * * *$ & 0.147 & -7.070 & 0.000 \\
\hline LnGHGE(-1) & -1.070 & 2.230 & -0.478 & 0.634 \\
\hline LnNUEN(-1) & $1.852^{* * *}$ & 0.598 & 3.094 & 0.003 \\
\hline $\operatorname{LnCOEN(-1)}$ & $-0.000^{* * *}$ & 0.000 & -2.755 & 0.009 \\
\hline LnURAG(-1) & -1.850 & 3.390 & -0.547 & 0.587 \\
\hline $\mathrm{D}(\mathrm{GHGE})$ & 6.090 & 4.530 & 1.345 & 0.186 \\
\hline D(NUEN) & $2.957 * * *$ & 0.885 & 3.342 & 0.001 \\
\hline $\mathrm{D}(\mathrm{COEN})$ & $0.000 *$ & 0.000 & 1.857 & 0.071 \\
\hline D(URAG) & 1.205 & 7.736 & 1.555 & 0.128 \\
\hline $\operatorname{ECM}(-1)$ & $-1.039^{* * *}$ & 0.124 & -8.366 & 0.000 \\
\hline \multicolumn{5}{|c|}{ Long-Run Results } \\
\hline Variables & Coefficients & S-Error & t-Stat. & Prob. \\
\hline LnGHGE & -1.035 & 2.135 & -0.482 & 0.632 \\
\hline LnNUEN & $1.781 * * *$ & 0.524 & 3.395 & 0.001 \\
\hline LnCOEN & $-0.000 * *$ & 0.000 & -2.507 & 0.016 \\
\hline LnURAG & -1.787 & 3.280 & -0.543 & 0.589 \\
\hline C & -1.465 & 2.385 & -0.614 & 0.542 \\
\hline $\mathrm{R}^{2}$ & \multicolumn{2}{|c|}{0.661} & $\begin{array}{l}\text { M-Dependent } \\
\text { var }\end{array}$ & 0.003 \\
\hline Adj-R2 & \multicolumn{2}{|c|}{0.629} & S.D.D var & 2.493 \\
\hline S.E-regression & \multicolumn{2}{|c|}{1.518} & AIC & 3.773 \\
\hline S-S resid & \multicolumn{2}{|c|}{96.848} & $\mathrm{SC}$ & 3.970 \\
\hline Log-likelihood & \multicolumn{2}{|c|}{-83.680} & HQC & 3.847 \\
\hline D-W stat & \multicolumn{2}{|c|}{2.114} & & \\
\hline
\end{tabular}

Note: ${ }^{*}, * *, * *$ indicate the level of significance at $1 \%, 5 \%$, and $10 \%$.

Global civilization has experienced a significant transformation in urbanization and the growth of the construction sector during the last several decades. The building industry's transition from a developing society to a civilized one and high-level development are intertwined issues. Massive energy expenditures are the driving force for urbanization, building sector expansion, and strong economic performance [78,79]. Globalization, urbanization, and regional economic integration have all increased, making urban agglomeration an increasingly significant element of spatial organization and a worldwide problem. This has increased the importance of regional collaboration and communication. To some degree, urban agglomeration has been transformed and promoted due to globalization. 
Urban agglomeration is widely regarded as a tool for managing regionalization in a region, and urban research has increasingly focused on it [80,81]. Demand for energy and other associated services have risen in recent decades to satisfy the demands of global society and economic growth. Diverse economies encourage investment and financial output by participating in international resource exchanges where many businesses engage. As energy resources have increased in value, environmental deterioration and greenhouse gas emissions have risen sharply as well [82,83].

As a result of global warming, humanity as a species and the growth of the global economy are in grave danger. It also puts stability, natural life, and development at jeopardy. The rise in greenhouse gas emissions is mostly to blame for climate change. Human actions, like the extraction of nonrenewable resources, are also responsible for greenhouse gas emissions. Global warming occurs as a result of this. Increased carbon dioxide emissions are accelerating global warming, which is resulting in more severe weather events, such as more frequent floods, storms, glacier melt, droughts, and rising sea levels. When fossil fuels are used, carbon dioxide is released into the atmosphere, which causes climate change. Environmental pollution, mostly as a result of greenhouse gas emissions from economic activity, is posing an increasing number of challenges for the global economy, leading many decision-makers to spend substantial amounts of money to minimize the dangers [84-86]. The mix of energy growth elements demonstrates the model's unique character even more. As a result of advances in energy efficiency, industrialized and developing nations alike are shifting to cleaner forms of energy use. There is also a new focus on energy and economic development based on current research, although the findings are unclear. When it comes to promoting global economic development, attempts to reduce energy consumption, particularly from conventional energy sources, have an environmental effect. However, the economic impact of energy usage continues to dominate the narrative of contemporary research [87-89]. Another issue is the widespread reliance on fossil fuels in the emerging economies like Pakistan. Considering that these energy sources are not renewable or nuclear, they will run out in a matter of decades. While fossil fuels have a great influence on the environment, renewable and nuclear energy have less impact. Furthermore, nuclear and renewable energy may decrease $\mathrm{CO}_{2}$ emissions, aid in environmental protection, and lessen reliance on imports from other economies. The use of the nuclear energy with the renewable sources seems to be the answer to addressing energy security concerns while also helping to slow down the rate of the global warming $[50,90]$. The burning of fossil fuels emits greenhouse gases (GHGs) such as carbon dioxide $\left(\mathrm{CO}_{2}\right)$, which is usually recognized as the principal causes of global warming and climate change. Nuclear power, in particular, is expected to help countries reduce carbon dioxide emissions while expanding their economies. As a result, experts are now looking at the consequences of nuclear power production on carbon dioxide emissions, which is under-investigated by other prior studies. Nuclear power is seen as a feasible alternative to fossil fuels or hydrocarbon-based energy. Nuclear energy is a better alternative for transportation than fossil fuels, since it is more efficient. Nuclear energy might potentially be used to power vehicles such as trucks and trains. Nuclear energy has the potential to replace fossil fuel-burning power facilities in both mature and emerging economies [91,92]. The stability and diagnostics test results are included in the Table 7.

Table 7. Outcomes of stability and diagnostic tests.

\begin{tabular}{ccc}
\hline Statistics of Test & F-Stat & $p$-Values \\
\hline Breusch-Godfrey serial correlation LM test & 0.393 & 0.677 \\
\hline Heteroskedasticity test (Breusch-Pagan-Godfrey) & 0.718 & 0.688 \\
\hline CUSUM & & Stable \\
\hline CUSUM of squares & & Stable \\
\hline
\end{tabular}


The plots of the CUSUM and its squares at the 5\% level of significance are illustrated in Figure 3. Similarly, the long-term interaction among variables is expressed in the Figure 4.

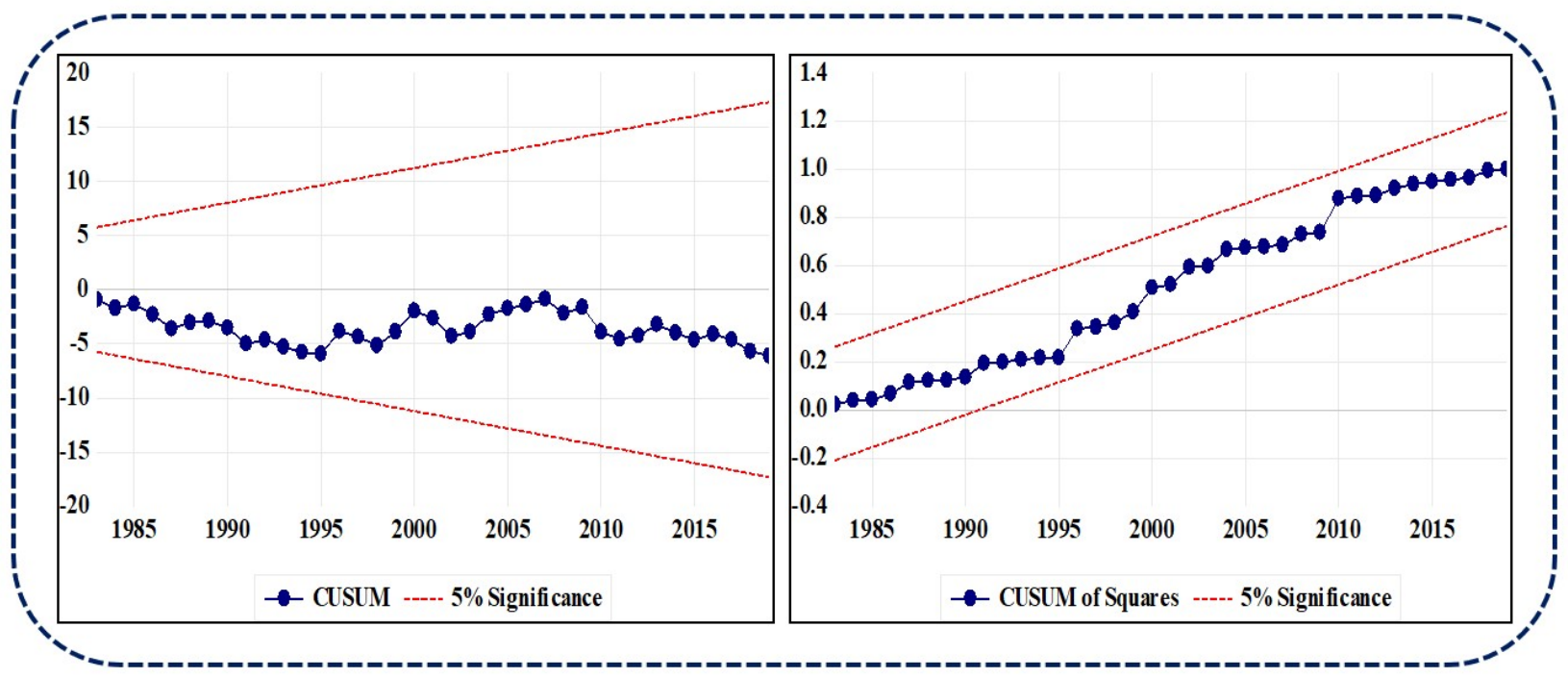

Figure 3. Plot of CUSUM and its squares.

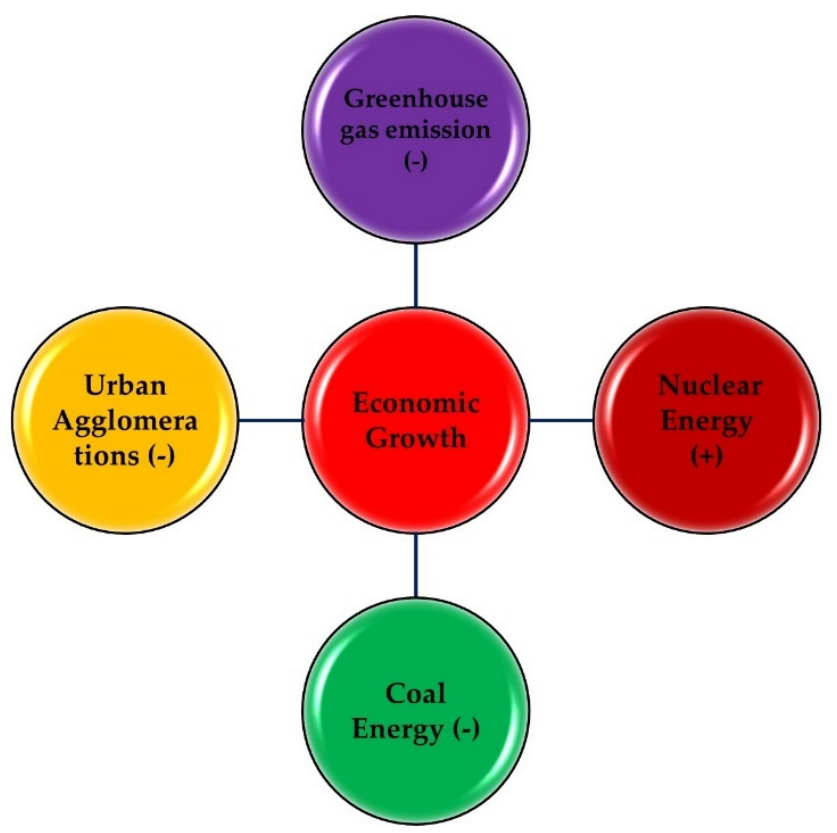

Figure 4. Interaction between variables.

The plot of Figure 4 reveals that all variables, including GHG emissions, nuclear energy consumption, coal energy consumption, and urban agglomeration, display either a positive or negative influence on the economic progress of Pakistan.

\subsection{Granger Causality Test}

Table 8 depicts the consequences of Granger's short-run causality test findings, and the addition of cointegration gives the relationship of variables used to analyze the directional causality through regressors. The ARDL method demonstrates a long-term relationship between research variables. Furthermore, the short-run Granger linkages indicate crucial implications for directing final conclusions, and indicators revealed a unidirectional relationship between economic growth and all other variables, including greenhouse gas emissions, nuclear energy, coal energy, urban agglomeration, and economic growth in 
Pakistan. As a result, Granger's VECM indicates a strong link between the variables under consideration.

Table 8. Causality results.

\begin{tabular}{cccccc}
\hline \multirow{2}{*}{$\begin{array}{c}\text { Dependent } \\
\text { Variables }\end{array}$} & \multicolumn{5}{c}{ Independent Variables } \\
\cline { 2 - 6 } & $\Delta$ LnECG & $\Delta$ LnGHGe & $\Delta$ LnNUEN & $\Delta$ LnCOEN & $\Delta$ LnURAG \\
\hline$\Delta$ LnECG & - & $0.010^{* *}$ & $0.021^{* *}$ & 0.048 & $0.000^{* * *}$ \\
$\Delta$ LnGHGe & 6.847 & - & 0.632 & 1.460 & $0.022^{* *}$ \\
$\Delta$ LnNUEN & 1.203 & $0.053^{*}$ & - & 0.256 & $0.003^{* * *}$ \\
$\Delta$ LnCOEN & 1.269 & $0.056^{*}$ & 0.117 & - & $0.004^{* * *}$ \\
$\Delta$ LnURAG & 4.186 & 3.854 & 5.042 & 4.498 & - \\
\hline
\end{tabular}

Note: ${ }^{*}, * * * * *$ demonstrate the level of significance at $1 \%, 5 \%$, and $10 \%$.

Figure 5 demonstrates the impulse response function and variance decomposition analysis showing up to 60 periods among all variables, including greenhouse gas emissions, nuclear energy, coal energy, urban agglomeration, and economic growth in Pakistan.

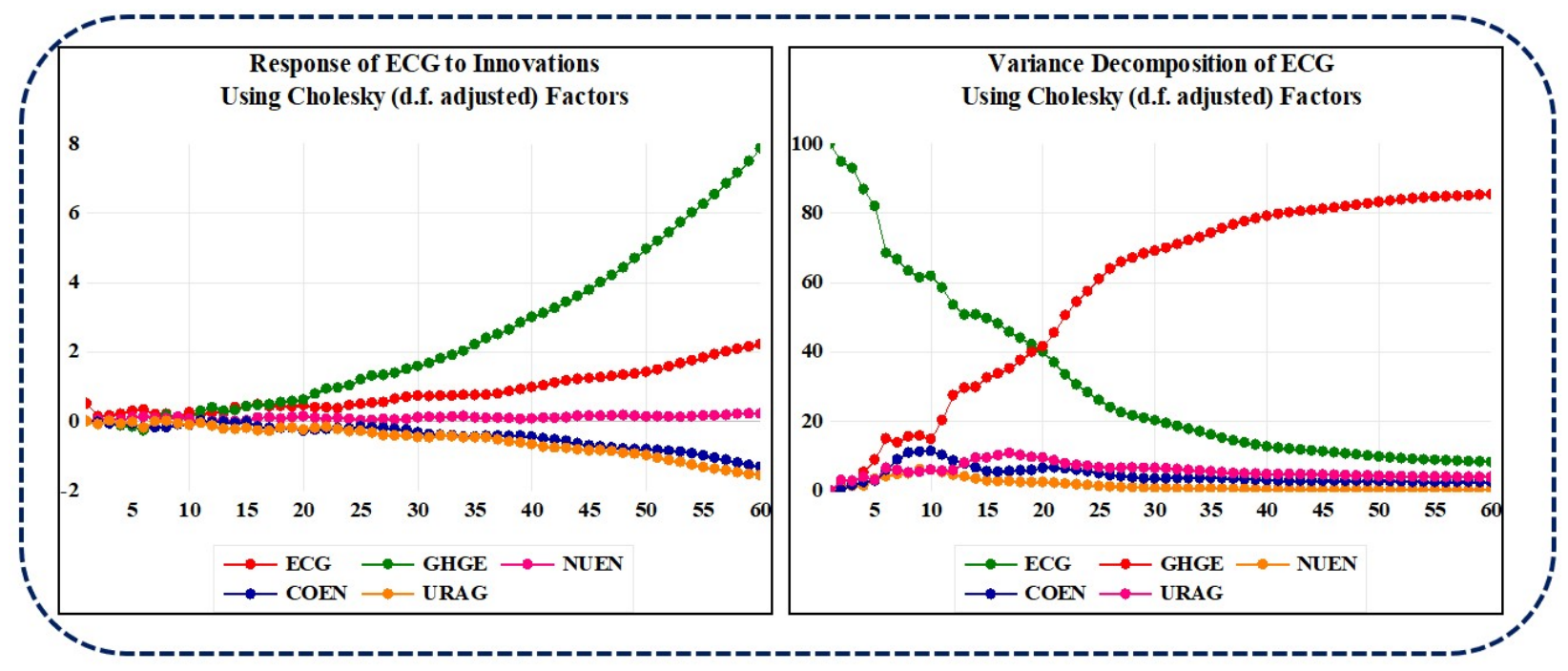

Figure 5. Impulse response function and variance decomposition analysis.

\subsection{Stepwise Least Squares Technique}

This study also utilized the stepwise least squares technique to uncover the linkage of variables to the economic growth; outcomes are depicted in Table 9.

Table 9. Results of stepwise least square.

\begin{tabular}{ccccc}
\hline Variables & Coefficients & S-Error & T-Stat. & Prob. \\
\hline LnGHGE & -2.640 & 2.000 & -1.316 & 0.195 \\
LnNUEN & $1.734^{* * *}$ & 0.554 & 3.128 & 0.003 \\
LnCOEN & -0.000 & 0.000 & -0.813 & 0.420 \\
LnURAG & 2.140 & 2.270 & 0.941 & 0.351 \\
C & 1.117 & 1.677 & 0.666 & 0.508 \\
$\mathrm{R}^{2}$ & 0.299 & MD- var & 4.790 \\
Adj-R & 0.233 & S.D. dependent var & 2.095 \\
S.E. of regression & 1.834 & AIC & 4.149 \\
S-S resid & 144.722 & SC & 4.344 \\
Log-likelihood & -94.595 & HQC & 1.223 \\
F-statistic & 4.586 & D-Watson stat \\
Prob(F-statistic) & 0.003 & \multicolumn{2}{c}{} \\
\hline
\end{tabular}

Note: ${ }^{* * *}$ indicates the level of significance at $10 \%$. 
Table 9 findings show that the variables nuclear energy consumption and urban agglomeration have positive coefficients that demonstrate a productive linkage to economic growth, while the other variables GHG emissions and coal energy consumption have adverse associations with economic growth in Pakistan. The value $R^{2}$, adj- $R^{2}$, F-statistic, AIC, SC, and DW are (0.299), (0.233), (4.586), (4.149), (4.344), and (1.815), correspondingly.

\section{Conclusions and Policy Recommendations}

In this analysis, we have examined the interaction between GHG emissions, nuclear energy, coal energy, urban agglomeration, and economic growth in Pakistan by utilizing annual sequence data series during 1972-2019. To ensure that the variables remained stationary, three different unit root tests were performed. An ARDL (autoregressive distributed lag) technique with short and long-run estimations was applied to uncover the interaction amid variables. A unidirectional connection between all variables was revealed by performing a Granger causality test under the vector error correction model (VECM). Furthermore, this analysis also utilized the stepwise least squares technique to reveal the association of the variables. The outcomes of long-run estimations show that GHG emissions, coal energy, and urban agglomeration reveal an adversative linkage to economic growth in Pakistan, while nuclear energy showed a productive association to economic growth. The findings of short-run analysis also show that nuclear energy has a constructive association to economic growth, while other variables exposed an adversative linkage to economic progress in Pakistan. Outcomes of the Granger causality test under the vector error correction model (VECM) show that all variables have unidirectional linkages. Moreover, the outcomes of the stepwise least squares technique reveal that GHG emissions and coal energy have a negative association with economic growth, and nuclear energy and urban agglomeration have a productive linkage to economic growth in Pakistan.

The increase of power production and transmission capacity are helping Pakistan overcome its current energy crisis, with positive effects seen throughout the economy as a whole. Now that energy has to be improved, it is necessary to provide it at a reduced cost and address other energy-related issues. Apart from the major hydroelectric projects currently underway, the present administration is also searching for renewable energy sources that may save money, in order to enhance the country's existing energy system. Following this study's findings, new possible steps are required from the Pakistan government to introduce fresh policies regarding environmental sustainability in order to reduce the carbon emissions. GHG emissions are unquestionably a growing global concern, requiring prudent policies and financial assistance to address this issue. Pakistan contributes fewer GHG emissions than industrialized countries; however, the government must take new steps to address this issue and help to contribute to environmental sustainability as a way to boost economic development. There has been an enormous rise in energy consumption over the past century as a result of different breakthroughs and everyday usage. Because of this, almost every aspect of human life has become more reliant on energy. Reliable and cheap energy is critical for all economies, but it is especially critical for developing countries. Increased industrialization, modernization, commerce, and better transportation have all contributed to a rise in energy consumption in these economies. It is imperative that Pakistan's chaotic and inefficient energy industry be brought under control and made more efficient. Energy sector coordination and integration may be improved by bringing together many national energy agencies under one ministry. Pakistan's energy industry may better coordinate planning, decision-making, and execution with stricter institutional frameworks. The energy system needs to be more diverse. Importing clean coal may be used as a starting point since it is less expensive than importing crude oil or natural gas. In the absence of investment in domestic resources such as water power, natural gas, and lignite, Pakistan remains reliant on energy imports. The biggest source of energy is biomass. The government has decided to halt the construction of new coal-fired power plants due to environmental concerns. Future research can be conducted because this study does not have any limitations. Pakistan can obtain benefits from paying attention to cheaper energy 
resources including solar, wind, and hydropower, instead of using oil, coal, and gas, which cause pollution and disturb the environment.

Author Contributions: Conceptualization, A.R. and M.R.; methodology, A.R. and H.M.; software, H.M. and M.S.A.; validation, A.R., H.M. and M.R.; formal analysis, A.R. and R.A.; investigation, C.I.S. and L.M.P.; data curation, A.R.; writing-original draft preparation, L.M.P.; writing-review and editing, A.R. and M.R.; visualization, R.A.; supervision, R.A.; project administration, A.R. All authors have read and agreed to the published version of the manuscript.

Funding: This research received no external funding.

Institutional Review Board Statement: Not applicable.

Informed Consent Statement: Not applicable.

Data Availability Statement: Data can be found at the links indicated into the text in Section 3.

Conflicts of Interest: The authors declare no conflict of interest.

\section{References}

1. GOP. Pakistan Economic Survey (2019-20), Government of Pakistan. 2020. Available online: https://www.finance.gov.pk/ survey / chapter_20/14_Energy.pdf (accessed on 14 September 2021).

2. GOP. Pakistan Economic Survey (2015-16), Government of Pakistan. 2016. Available online: https://www.finance.gov.pk/ survey / chapter_16/14_Energy.pdf (accessed on 14 September 2021).

3. GOP. Pakistan Economic Survey (2017-18), Government of Pakistan. 2018. Available online: https://www.finance.gov.pk/ survey/chapters_18/14-Energy.pdf (accessed on 14 September 2021).

4. GOP. Pakistan Economic Survey (2018-19), Government of Pakistan. 2019. Available online: https://www.finance.gov.pk/ Supplement_2018_19.pdf (accessed on 14 September 2021).

5. Jaforullah, M.; King, A. Does the use of renewable energy sources mitigate $\mathrm{CO}_{2}$ emissions? A reassessment of the US evidence. Energy Econ. 2015, 49, 711-717. [CrossRef]

6. Jin, T.; Kim, J. What is better for mitigating carbon emissions-Renewable energy or nuclear energy? A panel data analysis. Renew. Sustain. Energy Rev. 2018, 91, 464-471. [CrossRef]

7. York, R.; McGee, J.A. Does Renewable Energy Development Decouple Economic Growth from $\mathrm{CO}_{2}$ Emissions? Socius 2017, 3 , 2378023116689098. [CrossRef]

8. Intergovernmental Panel on Climate Change (IPCC). Mitigation of Climate Change: Energy Systems; Fifth Assessment Report; IPCC: Geneva, Switzerland, 2014.

9. Sadeghi, A.; Larimian, T. Sustainable electricity generation mix for Iran: A fuzzy analytic network process approach. Sustain. Energy Technol. Assess. 2018, 28, 30-42. [CrossRef]

10. Oryani, B.; Koo, Y.; Rezania, S. Structural vector autoregressive approach to evaluate the impact of electricity generation mix on economic growth and $\mathrm{CO}_{2}$ emissions in Iran. Energies 2020, 13, 4268. [CrossRef]

11. Rehman, A.; Ma, H.; Ozturk, I.; Ahmad, M.; Rauf, A.; Irfan, M. Another outlook to sector-level energy consumption in Pakistan from dominant energy sources and correlation with economic growth. Environ. Sci. Pollut. Res. 2021, 28, 33735-33750. [CrossRef]

12. Fassio, F.; Tecco, N. Circular Economy for Food: A Systemic Interpretation of 40 Case Histories in the Food System in Their Relationships with SDGs. Systtems 2019, 7, 43. [CrossRef]

13. Clube, R.K.; Tennant, M. The Circular Economy and human needs satisfaction: Promising the radical, delivering the familiar. Ecol. Econ. 2020, 177, 106772. [CrossRef]

14. Schröder, P.; Lemille, A.; Desmond, P. Making the circular economy work for human development. Resour. Conserv. Recycl. 2020, 156, 104686. [CrossRef]

15. Padilla-Rivera, A.; Carmo, B.B.T.D.; Arcese, G.; Merveille, N. Social circular economy indicators: Selection through fuzzy delphi method. Sustain. Prod. Consum. 2021, 26, 101-110. [CrossRef]

16. Zimon, D.; Tyan, J.; Sroufe, R. Drivers of sustainable supply chain management: Practices to alignment with un sustainable development goals. Int. J. Qual. Res. 2020, 14, 219-236. [CrossRef]

17. Fonseca, L.M.; Domingues, J.P.; Pereira, M.T.; Martins, F.F.; Zimon, D. Assessment of circular economy within Portuguese organizations. Sustainability 2018, 10, 2521. [CrossRef]

18. Gohar, A.; Nencioni, G. The Role of 5G Technologies in a Smart City: The Case for Intelligent Transportation System. Sustainability 2021, 13, 5188. [CrossRef]

19. Kahia, M.; Jebli, M.B.; Belloumi, M. Analysis of the impact of renewable energy consumption and economic growth on carbon dioxide emissions in 12 MENA countries. Clean Technol. Environ. Policy 2019, 21, 871-885. [CrossRef]

20. Soava, G.; Mehedintu, A.; Sterpu, M.; Raduteanu, M. Impact of Renewable Energy Consumption on Economic Growth: Evidence from European Union Countries. Technol. Econ. Dev. Econ. 2018, 24, 914-932. [CrossRef] 
21. Awodumi, O.B.; Adeleke, A.M. Non-Renewable Energy and Macroeconomic Efficiency of Seven Major Oil Producing Economies in Africa. Zagreb Int. Rev. Econ. Bus. 2016, 19, 59-74. [CrossRef]

22. Hanif, I.; Aziz, B.; Chaudhry, I.S. Carbon emissions across the spectrum of renewable and non-renewable energy use in developing economies of Asia. Renew. Energy 2019, 143, 586-595. [CrossRef]

23. Murshed, M.; Alam, M.S. Estimating the macroeconomic determinants of total, renewable, and non-renewable energy demands in Bangladesh: The role of technological innovations. Environ. Sci. Pollut. Res. 2021, 28, 30176-30196. [CrossRef]

24. Zhang, L.; Pang, J.; Chen, X.; Lu, Z. Carbon emissions, energy consumption and economic growth: Evidence from the agricultural sector of China's main grain-producing areas. Sci. Total Environ. 2019, 665, 1017-1025. [CrossRef]

25. Marinas, M.-C.; Dinu, M.; Socol, A.-G.; Socol, C. Renewable energy consumption and economic growth. Causality relationship in Central and Eastern European countries. PLoS ONE 2018, 13, e0202951. [CrossRef]

26. Chen, C.; Pinar, M.; Stengos, T. Renewable energy consumption and economic growth nexus: Evidence from a threshold model. Energy Policy 2020, 139, 111295. [CrossRef]

27. Govindaraju, V.G.R.C.; Tang, C.F. The dynamic links between $\mathrm{CO}_{2}$ emissions, economic growth and coal consumption in China and India. Appl. Energy 2013, 104, 310-318. [CrossRef]

28. Shahbaz, M.; Raghutla, C.; Chittedi, K.R.; Jiao, Z.; Vo, X.V. The effect of renewable energy consumption on economic growth: Evidence from the renewable energy country attractive index. Energy 2020, 207, 118162. [CrossRef]

29. Salari, M.; Javid, R.J.; Noghanibehambari, H. The nexus between $\mathrm{CO}_{2}$ emissions, energy consumption, and economic growth in the U.S. Econ. Anal. Policy 2021, 69, 182-194. [CrossRef]

30. Wang, Z.; Danish, Z.B.; Wang, B. Renewable energy consumption, economic growth and human development index in Pakistan: Evidence form simultaneous equation model. J. Clean. Prod. 2018, 184, 1081-1090. [CrossRef]

31. Mahmood, N.; Wang, Z.; Hassan, S.T. Renewable energy, economic growth, human capital, and $\mathrm{CO}_{2}$ emission: An empirical analysis. Environ. Sci. Pollut. Res. 2019, 26, 20619-20630. [CrossRef] [PubMed]

32. Khan, M.K.; Teng, J.-Z.; Khan, M.I. Effect of energy consumption and economic growth on carbon dioxide emissions in Pakistan with dynamic ARDL simulations approach. Environ. Sci. Pollut. Res. 2019, 26, 23480-23490. [CrossRef]

33. Lee, S.-H.; Jung, Y. Causal dynamics between renewable energy consumption and economic growth in South Korea: Empirical analysis and policy implications. Energy Environ. 2018, 29, 1298-1315. [CrossRef]

34. Ullah, A.; Ahmed, M.; Raza, S.A.; Ali, S. A threshold approach to sustainable development: Nonlinear relationship between renewable energy consumption, natural resource rent, and ecological footprint. J. Environ. Manag. 2021, 295, 113073. [CrossRef] [PubMed]

35. Zhang, B.; Wang, B.; Wang, Z. Role of renewable energy and non-renewable energy consumption on EKC: Evidence from Pakistan. J. Clean. Prod. 2017, 156, 855-864. [CrossRef]

36. Mahmood, N.; Danish, W.Z.; Zhang, B. The role of nuclear energy in the correction of environmental pollution: Evidence from Pakistan. Nucl. Eng. Technol. 2020, 52, 1327-1333. [CrossRef]

37. Dong, K.; Sun, R.; Jiang, H.; Zeng, X. $\mathrm{CO}_{2}$ emissions, economic growth, and the environmental Kuznets curve in China: What roles can nuclear energy and renewable energy play? J. Clean. Prod. 2018, 196, 51-63. [CrossRef]

38. Rehman, A.; Ma, H.; Radulescu, M.; Sinisi, C.I.; Yousaf, Z. Energy Crisis in Pakistan and Economic Progress: Decoupling the Impact of Coal Energy Consumption in Power and Brick Kilns. Mathematics 2021, 9, 2083. [CrossRef]

39. Zhang, B.; Wang, Z.; Wang, B. Energy production, economic growth and $\mathrm{CO}_{2}$ emission: Evidence from Pakistan. Nat. Hazards 2017, 90, 27-50. [CrossRef]

40. Ahmad, N.; Du, L. Effects of energy production and $\mathrm{CO}_{2}$ emissions on economic growth in Iran: ARDL approach. Energy 2017, 123, 521-537. [CrossRef]

41. Begum, R.A.; Sohag, K.; Abdullah, S.M.S.; Jaafar, M. $\mathrm{CO}_{2}$ emissions, energy consumption, economic and population growth in Malaysia. Renew. Sustain. Energy Rev. 2015, 41, 594-601. [CrossRef]

42. Rehman, A.; Rauf, A.; Ahmad, M.; Chandio, A.A.; Deyuan, Z. The effect of carbon dioxide emission and the consumption of electrical energy, fossil fuel energy, and renewable energy, on economic performance: Evidence from Pakistan. Environ. Sci. Pollut. Res. 2019, 26, 21760-21773. [CrossRef] [PubMed]

43. Sharif, A.; Raza, S.A.; Ozturk, I.; Afshan, S. The dynamic relationship of renewable and nonrenewable energy consumption with carbon emission: A global study with the application of heterogeneous panel estimations. Renew. Energy 2019, 133, 685-691. [CrossRef]

44. Rehman, S.A.U.; Cai, Y.; Mirjat, N.H.; Walasai, G.D.; Nafees, M. Energy-environment-economy nexus in Pakistan: Lessons from a PAK-TIMES model. Energy Policy 2019, 126, 200-211. [CrossRef]

45. Rehman, A.; Radulescu, M.; Ma, H.; Dagar, V.; Hussain, I.; Khan, M.K. The Impact of Globalization, Energy Use, and Trade on Ecological Footprint in Pakistan: Does Environmental Sustainability Exist? Energies 2021, 14, 5234. [CrossRef]

46. Abbasi, K.; Jiao, Z.; Shahbaz, M.; Khan, A. Asymmetric impact of renewable and non-renewable energy on economic growth in Pakistan: New evidence from a nonlinear analysis. Energy Explor. Exploit. 2020, 38, 1946-1967. [CrossRef]

47. Maxim, A. Sustainability assessment of electricity generation technologies using weighted multi-criteria decision analysis. Energy Policy 2014, 65, 284-297. [CrossRef]

48. Rehman, A.; Deyuan, Z. Investigating the Linkage between Economic Growth, Electricity Access, Energy Use, and Population Growth in Pakistan. Appl. Sci. 2018, 8, 2442. [CrossRef] 
49. Magazzino, C.; Mele, M.; Schneider, N.; Vallet, G. The relationship between nuclear energy consumption and economic growth: Evidence from Switzerland. Environ. Res. Lett. 2020, 15, 0940. [CrossRef]

50. Saidi, K.; Mbarek, M.B. Nuclear energy, renewable energy, $\mathrm{CO}_{2}$ emissions, and economic growth for nine developed countries: Evidence from panel Granger causality tests. Prog. Nucl. Energy 2016, 88, 364-374. [CrossRef]

51. Christoforidis, T.; Katrakilidis, C.; Karakotsios, A.; Dimitriadis, D. The dynamic links between nuclear energy and sustainable economic growth. Do institutions matter? Prog. Nucl. Energy 2021, 139, 103866. [CrossRef]

52. Mbarek, M.B.; Nasreen, S.; Feki, R. The contribution of nuclear energy to economic growth in France: Short and long run. Qual. Quant. 2017, 51, 219-238. [CrossRef]

53. Yue, W.; Cai, Y.; Xu, L.; Tan, Q.; Yin, X. Adaptation strategies for mitigating agricultural GHG emissions under dual-level uncertainties with the consideration of global warming impacts. Stoch. Environ. Res. Risk Assess. 2017, 31, 961-979. [CrossRef]

54. Yao, X.; Zhou, H.; Zhang, A.; Li, A. Regional energy efficiency, carbon emission performance and technology gaps in China: A meta-frontier non-radial directional distance function analysis. Energy Policy 2015, 84, 142-154. [CrossRef]

55. Khan, Z.U.; Awan, M.S. Impact of Urban Agglomeration on Economic Growth of Cities. Rev. Econ. Dev. Stud. 2017, 3, 167-181. [CrossRef]

56. Ahrend, R.; Lembcke, A.; Schumann, A. The Role of Urban Agglomerations for Economic and Productivity Growth. Int. Product. Monit. 2017, 32, 161-179.

57. Asogwa, F.O.; Amuka, J.I.; Igwe, A.A.; Nkalu, C.N. Dynamics of population, urban agglomeration, and economic growths in Sub-Saharan Africa: Evidence from panel data. J. Public Aff. 2020, e2447. [CrossRef]

58. Jayasooriya, S.P. Urban agglomeration and regional economic growth in China. World 2019, 33, 36.

59. Liu, B.; Du, J. Empirical analysis of the spatial relationship between urban agglomeration economic network and economic growth based on big data. J. Physics: Conf. Ser. 2021, 1800, 012008. [CrossRef]

60. Ali, S.; Wahid, F.; Ali, A. Role of Energy in Economic Growth of Pakistan (1972-2015). Glob. Soc. Sci. Rev. 2019, 4, 158-164. [CrossRef]

61. Santos, J.; Domingos, T.; Sousa, T.; Aubyn, M.S. Useful Exergy Is Key in Obtaining Plausible Aggregate Production Functions and Recognizing the Role of Energy in Economic Growth: Portugal 1960-2009. Ecol. Econ. 2018, 148, 103-120. [CrossRef]

62. Urban, F.; Nordensvärd, J. Low Carbon Energy Transitions in the Nordic Countries: Evidence from the Environmental Kuznets Curve. Energies 2018, 11, 2209. [CrossRef]

63. Hu, Y.; Guo, D.; Wang, M.; Zhang, X.; Wang, S. The Relationship between Energy Consumption and Economic Growth: Evidence from China's Industrial Sectors. Energies 2015, 8, 9392-9406. [CrossRef]

64. Pesaran, M.H.; Shin, Y. An autoregressive distributed lag modelling approach to 583 cointegration analysis. Econom. Soc. Monogr. 1998, 31, 371-413.

65. Pesaran, M.H.; Shin, Y.; Smith, R.J. Bounds testing approaches to the analysis of level relationships. J. Appl. Econom. 2001, 16, 289-326. [CrossRef]

66. Engle, R.F.; Granger, C.W. Co-Integration and Error Correction: Representation, Estimation, and Testing. Economy 1987, 55, 251. [CrossRef]

67. Dickey, D.A.; Fuller, W.A. Distribution of the Estimators for Autoregressive Time Series with a Unit Root. J. Am. Stat. Assoc. 1979, 74, 427. [CrossRef]

68. Phillips, P.C.; Perron, P. Testing for a unit root in time series regression. Biometrika 1998, 75, 335-346. [CrossRef]

69. Kwiatkowski, D.; Phillips, P.C.; Schmidt, P.; Shin, Y. Testing the null hypothesis of stationarity against the alternative of a unit root: How sure are we that economic time series have a unit root? J. Econom. 1992, 54, 159-178. [CrossRef]

70. Johansen, S.; Juselius, K. Maximum likelihood estimation and inference on cointegration-With appucations to the demand for money. Oxf. Bull. Econ. Stat. 1990, 52, 169-210. [CrossRef]

71. Gokmenoglu, K.; Kaakeh, M. Causal Relationship between Nuclear Energy Consumption and Economic Growth: Case of Spain. Strat. Plan. Energy Environ. 2018, 37, 58-76. [CrossRef]

72. Baloch, M.A.; Wang, B. Analysing the role of governance in $\mathrm{CO}_{2}$ emissions mitigation: The BRICS experience. Struct. Chang. Econ Dyn. 2019, 51, 119-125.

73. Baloch, M.A.; Mahmood, N.; Zhang, J.W. Effect of natural resources, renewable energy and economic development on $\mathrm{CO}_{2}$ emissions in BRICS countries. Sci. Total Environ. 2019, 678, 632-638. [CrossRef]

74. Ulucak, R.; Bilgili, F. A reinvestigation of EKC model by ecological footprint measurement for high, middle and low income countries. J. Clean. Prod. 2018, 188, 144-157. [CrossRef]

75. Wang, Z.; Zhang, B.; Wang, B. The moderating role of corruption between economic growth and $\mathrm{CO}_{2}$ emissions: Evidence from BRICS economies. Energy 2018, 148, 506-513. [CrossRef]

76. Leal, P.H.; Marques, A.C. Rediscovering the EKC hypothesis for the 20 highest $\mathrm{CO}_{2}$ emitters among OECD countries by level of globalization. Int. Econ. 2020, 164, 36-47. [CrossRef]

77. Li, S.; Shi, J.; Wu, Q. Environmental Kuznets Curve: Empirical Relationship between Energy Consumption and Eco-nomic Growth in Upper-Middle-Income Regions of China. Int. J. Environ. Res. Public Health 2020, 17, 6971. [CrossRef] [PubMed]

78. Amann, E.; Baer, W.; Trebat, T.; Lora, J.V. Infrastructure and its role in Brazil's development process. Q. Rev. Econ. Financ. 2016, 62, 66-73. [CrossRef] 
79. Ahmad, M.; Jabeen, G. Dynamic causality among urban agglomeration, electricity consumption, construction industry, and economic performance: Generalized method of moments approach. Environ. Sci. Pollut. Res. 2019, 27, 2374-2385. [CrossRef] [PubMed]

80. Ye, L. State-led metropolitan governance in China: Making integrated city regions. Cities 2014, 41, 200-208. [CrossRef]

81. Wu, F. China's emergent city-region governance: A new form of state spatial selectivity through state-orchestrated rescaling. Int J. Urban Reg. Res. 2016, 40, 1134-1151. [CrossRef]

82. Ahmad, N.; Du, L.; Tian, X.-L.; Wang, J. Chinese growth and dilemmas: Modelling energy consumption, $\mathrm{CO}_{2}$ emissions and growth in China. Qual. Quant. 2018, 53, 315-338. [CrossRef]

83. Luqman, M.; Ahmad, N.; Bakhsh, K. Nuclear energy, renewable energy and economic growth in Pakistan: Evidence from non-linear autoregressive distributed lag model. Renew. Energy 2019, 139, 1299-1309. [CrossRef]

84. Rjoub, H.; Odugbesan, J.A.; Adebayo, T.S.; Wong, W.-K. Sustainability of the Moderating Role of Financial Development in the Determinants of Environmental Degradation: Evidence from Turkey. Sustainability 2021, 13, 1844. [CrossRef]

85. Chen, Y.; Zhao, J.; Lai, Z.; Wang, Z.; Xia, H. Exploring the effects of economic growth, and renewable and non-renewable energy consumption on China's $\mathrm{CO}_{2}$ emissions: Evidence from a regional panel analysis. Renew. Energy 2019, 140, 341-353. [CrossRef]

86. Destek, M.A.; Aslan, A. Renewable and non-renewable energy consumption and economic growth in emerging economies: Evidence from bootstrap panel causality. Renew. Energy 2017, 111, 757-763. [CrossRef]

87. Shahbaz, M.; Khan, S.; Tahir, M.I. The dynamic links between energy consumption, economic growth, financial development and trade in China: Fresh evidence from multivariate framework analysis. Energy Econ. 2013, 40, 8-21. [CrossRef]

88. Arat, H.T.; Baltacioglu, M.K.; Tanç, B.; Sürer, M.G.; Dincer, I. A perspective on hydrogen energy research, development and innovation activities in Turkey. Int. J. Energy Res. 2020, 44, 588-593. [CrossRef]

89. Dincer, I.; Acar, C. A review on clean energy solutions for better sustainability. Int. J. Energy Res. 2015, 39, 585-606. [CrossRef]

90. Pao, H.-T.; Fu, H.-C. Renewable energy, non-renewable energy and economic growth in Brazil. Renew. Sustain. Energy Rev. 2013, 25, 381-392. [CrossRef]

91. Baek, J. A panel cointegration analysis of $\mathrm{CO}_{2}$ emissions, nuclear energy and income in major nuclear generating countries. Appl. Energy 2015, 145, 133-138. [CrossRef]

92. Agyekum, E.B.; Ansah, M.N.S.; Afornu, K.B. Nuclear energy for sustainable development: SWOT analysis on Ghana's nuclear agenda. Energy Rep. 2020, 6, 107-115. [CrossRef] 